\title{
COLONIAL WATERBIRDS BREEDING AT JUNCTION RESERVOIR, SASKATCHEWAN
}

\author{
by A. R. SMITH*
}

In 1907 the eminent naturalist Arthur Cleveland Bent wrote of the impressive numbers of waterbirds he saw at Crane, Bigstick and other lakes in southwestern Saskatchewan during the summers of 1905 and 1906.' His accounts of large numbers of Eared Grebes and Franklin's Gulls breeding at Lake of the Narrows, colonies of Double-crested Cormorants, White Pelicans, and California and Ringbilled gulls at Bigstick Lake, and an enormous Western Grebe colony at Crane Lake are particularly interesting.

The devastating drought of the Thirties turned these lakes into dustbowls; they never really recovered, for the breeding grounds are now silent. Fortunately, the same drought that destroyed these breeding grounds helped to create new nesting habitat. The need for a reliable water supply for recreation, irrigation and domestic use led to the creation of several major reservoirs in the southwest. The large number of grebes, cormorants, pelicans, ducks, geese and gulls attracted to these new areas would perhaps even astonish Bent.

In the summer of 1972 , I was a member of a Saskatchewan Department of Natural Resources banding crew; the project leader was biologist David S. Gray of Saskatoon. Our objective was to band flightless young and adult Canada Geese in the south-

* Canadian Wildlife Service. Edmonton, Alberta western part of the province. On June 25 we banded 15 Canada Geese on Junction Reservoir near the town of Maple Creek. During my visit there, I made notes on several species of waterbirds which were nesting on the islands and shores of the reservoir.

Junction Reservoir was formed by a dam on Maple Creek 5 miles below the town of Maple Creek (Figure 1). It derives its name from the junction of Highways 1 and 21,3 miles to the northeast. The water body is 2.5 miles long, and varies in width from 1.25 miles at the southern end to less than 0.25 miles at the central narrows. North of the narrows the reservoir is quite deep and practically devoid of aquatic vegetation. In marked contrast the southern end of the reservoir is relatively shallow and is choked with submerged aquatic vegetation (mainly water milfoil and green algae). Numerous islands and bays as well as the drowned channels of Gap and Maple creeks have created a haven for waterbirds.

The most conspicuous birds were the Double-crested Cormorants. They nested on a small island (A, Figure 1) about 75 yards across and located near the narrows. The island vegetation consisted of foxtail barley, pigweed, some rose and willow. About 105 cormorant nests were arranged in the form of a broad arc near the centre of the island. An additional 10 nests were found off one end of the arc. They were constructed of pigweed stems and 
About 200 pairs of Ring-billed Gulls were found nesting on a peninsula (C, Figure 1) about $2 / 3$ mile south of Island A. As with the California Gull, many of the young had fledged. Interspecific competition with the preceding species appears to have forced the Ring-billed Gulls to foresake the comparative safety of Island $A$ for a peninsula exposed to terrestrial predators. Vermeer in his studies of California and Ring-billed gulls nesting at Miquelon Lake in Alberta states that the California Gull is dominant over the Ring-billed Gull and therefore has its choice of nest sites. 3

Twenty-five Common Tern nests were found on an islet (B, Figure 1) near the Ring-billed Gull colony. From one to three eggs were found in each nest; the average clutch size was 2.1 eggs. This is somewhat lower than the usual three ${ }^{2}$, but incubation was so well advanced that the difference could be accounted for by predation and the fledging of young.

Forty-five pairs of Eared Grebes nested in the channel between Island B and Peninsula $C$. In contrast with the other colonial birds, which were fledging young, these birds were still laying eggs. Great Blue Herons, Canada Geese, several species of ducks and shorebirds filled out the complement of summer residents at Junction Reservoir.

On August 25, 1973, I returned to Junction Reservoir. Poor spring runoff and low summer precipitation had caused water levels on the reservoir to drop about 3 feet creating extensive mud flats. Islands (including Islands A and $B$ ) were turned into parts of the mainland. When I checked the cor morant nests on Island $A$, I found that they contained the egg shells or dead young of the White Pelican, Doublecrested Cormorant and an unknown species of gull, which indicated that these species bred in spite of the low water levels. Nesting success, however was probably poor.

Human interference appeared to be at a minimum. The shallow waters and dense aquatic vegetation of the southern end of the reservoir effectively discourage boaters from landing on the nesting sites; access by road is equally poor. The major threat to the colonies appears to be fluctuating water levels which could destroy the nesting islands or expose them to the ravages of terrestrial predators such as coyotes and skunks. Because many colonial waterbirds breed in relatively few locations in the province, the continued existence of the colonies at Junction Reservoir is of great importance. The colonies of cormorants and pelicans at the reservoir are of particular importance since there are fewer than a dozen active colonies of each species remaining in the province. ${ }^{4}$

'BENT. A. C. 1907. Summer hirds of soutluwestern Saskatchewain. Auk 24:407-430.

"BENT, A. C. 1963. Life histories of Nertl American gulls and terns. Dover Publications New York.

"VER MEER, K. 1970. Breeding biology of Califor nia und Ring-billed gulls. Can. Wildl. Serv. Rep Series 12. Ottawa.

'VER MEER, K. 1970. Colonies of Double-crested Cormorants and White Pelicans in Saskatchewan Can. Ficld-Nat. 84:39-42.

"VERMEER, K. 1970. Some aspects of the nestims of Dowble-crested Cormorants at Cypress Lake Saskatchewan, in 1969; a plea for protection. Blus Jay 28:11-14.

In the marsh, long windy waves surge across the grassy sloughs, beat against the far willows. A tree tries to argue, bare limbs waving, but there is no detaining the wind. Aldo Leopold. A Sand County Almanac. 